\title{
The Moral Philosophy of Capitalism in the View of the Javanese Islamic Trade Ethos
}

\author{
Daryono $^{1}$, Suparman Syukur ${ }^{2}$ \\ 1Iniversitas Semarang, Semarang - Indonesia \\ 2Universitas Islam Negeri Walisongo, Semarang - Indonesia \\ e-mail: 1daryono@usm.ac.id; ${ }^{2}$ suparman@walisongo.ac.id
}

\begin{abstract}
The results of this paper were based on library research which aimed to understand capitalism in terms of Javanese Muslim trade ethos based on the work of experts. On the one hand, there was a mismatch between the economic system of capitalism and the ethos for the objectification of Islam in commerce and the results were suitable for world views and cultural life. Java was in a postcolonial state on the other hand. The method of analyzing its understanding was through historical and normative social as well as normative ethics and metaethics. The analysis resulted in three characteristics of the theoretical construction of Javanese Muslim trade ethos as a way of being kind, namely respect and care for anything, respect and harmony or care for anyone and following the culture and religious experience of Javanese Muslims at that time. These three characteristics had been proven during the Mangkunegara IV period, capable of creating human progress in various fields of life, especially the Mangkunegaran kingdom, for example, it was called Kala Sumbaga (a prosperous period). Therefore, this theoretical construction was expected to be an alternative to ethical thinking and vision in trade at the regional or national level.
\end{abstract}

Keywords: Capitalism; Moral philosophy; Trade Ethos; Islam, Java

\section{A. Introduction}

Two important terms to clarify the meaning here are Javanese Muslims and Javanese Muslims. The first term, according to Kuntowidjojo ${ }^{1}$ is an objectification of Islam namely, the practice of Javanese Muslim beliefs in the trading tradition. This tradition is also perceived by non-Muslims as natural and natural, not as a religious act or being able to enjoy, accept without having to agree on its value from the Javanese Islamic religious beliefs. For example, the cooperation tradition is the Islamic objectification of ukhuwah. Therefore, the

${ }^{1}$ Kuntowidjojo, Identitas Politik Umat Islam (Bandung: Mizan, 1997), Pp. 69-70. 
analysis of this understanding for the Javanese Muslim trade ethos uses a historical and normative sociological approach. ${ }^{2}$

While the second term does not mean the religion of Java (The Religion of Java). Clifford Geertz thought that he divided it into three schools: santri, priyayi and abangan. ${ }^{3}$ Because, Marshal G.S. Hudgson from the University of Chicago called Gertz's interpretation of Javanese Islam highly misleading, with the three schools meaning that he had carelessly labelled the religious life of Muslims into Javanese "Hindu". ${ }^{4}$ He has also confused horizontal division (among people) with vertical (relationship with God). ${ }^{5}$ A priyayi may become a mixed Muslim: a pious Muslim as well as a statistical Muslim (santri and abangan) at the same time. ${ }^{6}$

Referring to the first and second explanations, both Javanese and Javanese Muslims, the depth of meaning is the objectification of Islam in Javanese tradition or culture. According to Hans Antlov, Javanese culture is a variety of ideas, norms, beliefs and values which cannot possibly be put together as a "unified whole" that is shared by the Javanese. Therefore understanding Javanese culture means analyzing the distribution and reproduction of knowledge which is very diverse in the world of life. ${ }^{7}$ On the one hand, this definition indicates that there are characteristics of Javanese culture with its world view ${ }^{8}$ and on the other hand the

\footnotetext{
2The socio-historical approach means analyzing the mutually beneficial coexistence of human life with evidence of its evolution in history, not legend or fiction. Meanwhile, the normative approach is an analysis related to moral values in order to live life properly under certain conditions. See Jean L Mc Kechnie (ed), Websters New Universal Unabridged Dictionary, (New York: The World Publishing Company), edition 2, 1972, p. 1799.

${ }^{3}$ Clifford Gertz, The Religion of Java, (New York: The Free Press), 1981, p. 48.

${ }^{4}$ Marshal G.S. Hodgson, Then Venture of Islam (Chicago: University of Chicago Press, 1974), p. 551.

5Zaini Muchtarom, Islam di Jawa dalam Perspektif Santri dan Abangan, (Jakarta: Salemba Diniyah), 2002), p. 17.

6Hasja W.Bachtiar,"The Religion of Java Commentary", dalam: Indonesian Journal of Cultural Studies, No,1, Vol.V, Januari 1973, p 90.

${ }^{7}$ Hans Antlov dan Sven Cederoth (ed.), Kepemimpinan Jawa: Perintah Halus Pemerintahan Otoriter, (Jakarta: YIO), 2001, p. 19.

8It means that the Javanese world view, namely, the whole descriptive belief about the Javanese relativeness, namely, nature, human beings and the supernatural (numinous or divine) is the unity of experience. Therefore, there is no difference in religious attitudes and there is no difference in essential principles. Franz Magnis Suseno, Etika Jawa Sebuah Analisa Falsafi terhadap Kebijaksanaan Hidup Jawa, (Jakarta: Gramedia, 2001), p. 81.
} 
objectification of Islam is practised in commerce so that it becomes a tradition for the world of life $e^{9}$ that is appropriate for its time.

Tradition contains morality, often called "ethos".10 The source of distribution and reproduction of Javanese culture as objectification of Islam by the morality of trade ethos of Javanese Muslims is summarized in Kejawen ${ }^{11}$, agama Jawi ${ }^{12}$ (Javanese religion) or literature of Islam kejawen (Javanese Islamic). ${ }^{13}$ Based on this explanation, it implies the theoretical construction ${ }^{14}$ of the Javanese Muslim trade ethos with success by the world view and the life of Javanese culture at its time. It is hoped that this theoretical construction, on the one hand, can understand the ethical characteristics (moral philosophy) of trade and the success of the Javanese Muslim trade ethos which are suitable both for the objectification of Islam and according to their time as well as on the other hand.

The analysis of this understanding is motivated by a negative opinion on Javanese culture in terms of trade, for example, the tradition of cooperation and feudal attitudes, in addition to being considered indulgent, it is also inappropriate or contrary to the way Westerners trade. 15 This assessment contradicts the

${ }^{9}$ The world of life is a reservoir of assumptions, a background organized in language in the form of a cultural tradition as a communication context as well as a reservoir of knowledge and presuppositions to take a stand. Franz Magnis Suseno, 12 Tokoh Etika Abad ke 20, (Yogyakarta: Kanisius, 2000), p. 223.

${ }^{10}$ Lorens Bagus, Kamus Filsafat, (Jakarta: Gramedia, 2002), p. 672.

${ }^{11}$ Kejawen (Javanism) is a descriptive term for elements of Javanese culture which are essentially and not a religious category, but rather as ethics and lifestyle in Javanese thought. Niels Mulder, Mistisisme Jawa Ideologi di Indonesia, (Yogakarta: LKiS, 2001), Pp. 10-11.

${ }^{12}$ Agama Jawi (Javanese religion), is a belief complex from the Hindu-Buddhist concept as a mystical Islamic unity. Koentjaraningrat, Kebudayaan Jawa, (Jakarta: Balai Pustaka, 1994), Pp. 312, 318.

13The Islam Kejawen (Javanese Islamic) literature is a library that combines Javanese traditions with Islamic mysticism called primbon, fiber, wirid and, suluk. Simuh, Mistik Islam Kejawen Raden Ngabehi Ranggawarsita: Suatu Studi terhadap Serat Wirid Hidayat Jati, (Jakarta: UI Press, 1988), p. 9.

${ }^{14}$ The point is theoretical construction, namely, a scheme or structure not from inductive conclusions nor from the results of deduction, but is built on the basis of interpretive certainty so that it can be understood logically to be projected or constructed to check how it works in reality and pay attention to whether the expected resultants can be achieved. Franz Magnis Suseno, Etika Jawa sebuah..., op cit., p. 4.

${ }^{15}$ Francois Raillon,"Dapatkah Orang Jawa Menjalankan Bisnis ? Bangkitnya Kapitalis Pribumi di Indonesia", dalam: Hans Antlov dan Sven Cederroth (ed.), Kepemimpinan Jawa...., Op. cit., Pp. 223-224. 
trading activities during the reign of King Mangkunegara IV in Mangkunegaran progressed, especially in the economic field, he was known as the foundation of the modern economy of his time. ${ }^{16}$

Magnis Suseno explained that the Javanese (Indonesian) trade ethos does not mean that it has to be a hybrid between Javanese traditional ethics and modern Western ethics. However, the Javanese trade ethos must be one hundred per cent modern in the sense that it must be determined based on the characteristics of their Javanese background, civilization, values, religious characteristics, world view and life. ${ }^{17}$ Therefore, the term "trade" here means not only as a buying and selling transaction, but more broadly, as a system of the economy ${ }^{18}$ by the characteristics of Javanese or Indonesian culture.

Referring to this explanation, Mubyarto put forward the Javanese Islamic trade ethos here. According to him, the Indonesian economic system is an economic system as a joint effort based on kinship and national cooperation, which is inspired by the Pancasila ideology. The system has a core of moral values as a basic reference for the spirit of the souls of its supporters, which regulates the mindset and actions of its economic actors. ${ }^{19}$ The economic system of Pancasila was neither completely different nor completely different from modern capitalism, namely that the colonial economy contained aspects of modern capitalism imported from Western Europe. Because of this, Indonesia has a dualistic economy: two side-by-side economic systems, namely a capitalistic system and a traditional feudal character. ${ }^{20}$

The two side-by-side economic systems may have been practised in the Javanese Muslim trade ethos with success by the king Mangkunegara IV (1853-

${ }^{16}$ Th.G.Th. Pegeaud, Pangeran Adipati Ario Mangkunagoro IV sebagai Pujangga, trans. RT Muhammad Husodo Pringgokusumo, (Surakarta: Reksopustoko Istana Mangkunegaran, 1987), p. 3. See also Pringgodigdo, Sejarah Perusahaan-Perusahaan Kerajaan Mangkunegaran, trans. R.T. Muhamamad Husodo Pringgokusumo, (Surakarta: Reksopustoko Istana Mangkunegaran, 1987), p. 47. 166.

17Franz Magnis Suseno, Berfilsafat dari Konteks, (Jakarta: Gramedia, 1992), Pp. 165-

${ }^{18}$ Economics as a social science, there are two, namely economics as a theory and which is applied to certain societies. Both affect cultural activities (for example art, science and religion), not only as appendages but economics as an integral part of human social life. Lorens Bagus, Kamus...., op. cit., p. 183.

${ }^{19}$ Mubyarto, Ekonomi Pancasila, (Jakarta: LP3S, 1993), p. 32.

${ }^{20}$ Ibid., p. 36. 
1881) when he governed Mangkunegaran. The proof is, although the government at that time was in a post-colonial condition, ${ }^{21}$ it was able to achieve progress, especially in the economic sector, as explained earlier. Magnis Suseno explained, if this Javanese trade ethos has been practised with evidence of the results, it will have a normative meaning as an attitude of will that is demanded to be developed. Considering that ethos is a responsible moral attitude, the demands for ethos enhancement contain accusations that the prevailing moral values have a bad will. Therefore, those who demand ethos know how other people must behave to become human beings, especially to be good traders. ${ }^{22}$

These various explanations imply the notion that the Pancasila economic system, mainly the Javanese Muslim trade ethos, has two views. First, as a critical attitude towards the ethics ${ }^{23}$ or moral philosophy of capitalism. What is meant here is critical not to determine moral norms, but to determine what is not the appropriate or valid way of Javanese Muslim trade ethos. Second, the view as a theoretical construction of the Javanese Muslim trade ethos with the success that is appropriate both in understanding the Javanese world view and according to its time and beyond. Therefore, this paper analyzes and understands both through normative and meta-ethical approaches ${ }^{24}$ as well as the views of the experts. The analysis and understanding of the first view are as follows.

\section{B. The Moral Philosophy of Capitalism in the View of Javanese Muslim Trade Ethics}

\footnotetext{
${ }^{21}$ The post-colonial condition means that the conditions were still significantly influenced by the colonialist politics, economy and culture. Fitzgeraid K. Sitorus, "Identitas Dekonstruksi Permanen", In Muji Sutrisno \& Hendar Putranto (ed.), Hermeneutik Pascakolonial Soal Identitas, (Yogyakarta: Kanisius, 2004), p. 170. The condition was like when Mangkunegara IV ruled Mangkunegaran, because he was under the Dutch colonial government who was Christian. Masroer Ch. Jb., Sejarah Perjumpaan Agama-agama di Jawa, (Yogyakarta: ar-Ruzz, 2004), p. 50.

22Franz Magnis Suseno, Berfilsafat dari Konteks, (Jakarta: Gramedia, 1992), p. 127.

${ }^{23}$ Ethics in the sense of the science of good and bad which is simply accepted in a society becomes a reflection material for a systematic and methodical study. Ethics in that sense means moral philosophy. K. Bertens, Etika, (Jakarta: Gramedia, 2005), p. 6.

${ }^{24}$ Normative ethics formulates ethical principles that can be practiced rationally, so it is not descriptive but prescriptive (ordered) and determines whether behavior or moral assumptions are true. While metaethics discusses utterances, moral language includes the logic of ethical sayings. Ibid., Pp. 15-16.
} 
Capitalism (English: capitalism), Latin word: caput (head). The word capital is associated with maintaining the head, life, welfare. Capitalism is an economic system that emphasizes the role of capital (capital), namely wealth in all its types, including goods used in other goods. Reference to capitalism thought, among others, Adam Smith and Max Weber. According to Adam Smith, human competitive efforts will automatically (from the invisible hand: the invisible hand) will turn into a common interest (common welfare). Meanwhile, according to Max Weber, there is a link between the rise of capitalism and Protestantism. Capitalism is a secular form of Protestantism to individualism and must work out for its salvation. ${ }^{25}$ According to Magnis Suseno, the characteristic of capitalism economy is that money is the goal as the highest value to gain its profit because only if the profit is large enough, entrepreneurs will survive the tough competition with other entrepreneurs. ${ }^{26}$ The economic characteristics of capitalism are consistent with Weber's view of the ethical aims of Protestant capitalism. $^{27}$

The first critical attitude of Javanese Muslim trade ethos is that the opinion of capitalism is incompatible with the inner meaning of trade ethos. Bertens explained that ethos refers to a distinctive atmosphere that includes work or profession. The meaning of "atmosphere" must be understood in a morally good sense. Therefore, if the ethos as a trader, of course, the ethos of trade tends to be less good if the only business objective is the maximization of profits in the form of money. ${ }^{28}$ Weber on the one hand agrees with Pietis, ${ }^{29}$ who views that by intensifying their ascetic life, they achieve happiness with God in the world. ${ }^{30}$ But

${ }^{25}$ Lorens Bagus, Kamus..., op. cit., Pp. 391-392.

${ }^{26}$ Franz Magnis Suseno, Pemikiran Karl Marx dari Sosialisme Utopis dan ke Perselisihan Revisionisme, (Jakarta: Gramedias, 1999), p. 164.

${ }^{27}$ According to Weber, Protestant capitalism ethics is the goal of human life for prosperity and wealth (money) for the sake of serving God, so people must remember "time is money" through industrialization with a serious strategy towards employees (laborers) and be very honest in one's relationships with others within the limits boundaries that have been formally outlined. Max Weber, The Protestant Ethic and the Spirit of Capitalism, translate by Talcott Parson, (New York: Charles Scribner's Son's, 1958), Pp. 48-49.

${ }^{28}$ K. Berten, Etika...., op. cit., Pp. 225-226.

${ }^{29}$ The Pietis is a spiritual renewal movement that began to develop in Western Europe at the end of the 17th century which grew out of the reformed Church in the Netherlands and Germany led by Philip Yacob Spener. Chonsul Schubert, "Pietism", The Encyclopedia Americana International Edition, (New York: Americana Corporation, 1974), Vol. 22, p. 77.

${ }^{30}$ Max Weber, The Protestant Ethic...., op. cit., p. 130. 
on the other hand, Weber argues that the goal of happiness in life is to get wealth and prosperity or prosperity. For this purpose one must remember "time is money". Such opinion implies the notion that happiness and the enjoyment of wealth money are the same as a measure of welfare or prosperity of life. According to normative ethics, this assumption is like in the theory of psychological hedonism, which argues that humans are essentially selfish people who only seek pleasure. ${ }^{31}$

According to Poespoprojo, enjoyment is not the same as happiness. Enjoyment is the pleasure or good feeling that is felt when a tendency is fulfilled. There are physical favours such as eating well to satisfy hunger or sexual favours for libido, there are also aesthetic or intellectual favours, and so on. The characteristic feature of pleasure is that it is directly related to an experience of the fulfilment of a tendency, once the experience is over, enjoyment also runs out. It is different in happiness. Happiness is an awareness of contentment and joy based on one's condition. Happiness is not attached to certain enjoyable experiences, so can he enjoy something without feeling happy. That is why sex does not guarantee happiness because after that the feeling of being unhappy can even get tighter. Likewise, the ability to buy various needs will not make us feel happy. ${ }^{32}$

Therefore, the meaning of "welfare" according to Weber is not by the true moral attitude ${ }^{33}$ as the basis for the creation of a state by human progress. ${ }^{34}$ There are two reasons for the mismatch. First, because Weber argues about Protestant morals as an insistent and unlimited pursuit of profit or wealth through industrialization. The systematic and merciless exploitation of labour and the utmost honesty in one's relations with others within the boundaries that

${ }^{31}$ Ali Mudhofir, Kamus Teori dan Aliran dalam Filsafat dan Teologi, (Yogyakarta: UGM Press, 1996), p. 55.

32Poespoprodjo, Filsafat Moral Kesusilaan dalam Teori dan Praktik, (Bandung: Pustaka Grafika, 1999), p. 150.

${ }^{33}$ Moral attitude which is actually the same as autonomy is obeying obligations, not imposed from outside, but because we are recognized as something that is good for ourselves and others and that is our responsibility, feeling proud to be able to overcome various low desires for the sake of responsibility is not easy, but always be happy. Franz Magnis Suseno, Etika Dasar: Masalah-Masalah Pokok Filsafat Moral, (Yogyakarta: Kanisius, 2005), Pp. 45-46.

${ }^{34}$ Humane progress is progress that makes human life feel more peaceful and safe, not enslaved and able to realize their dreams. Franz Magnis Suseno, Kuasa dan Moral, (Yogyakarta: Kanisius, 2001), p. 155. 
have been formally defined. ${ }^{35}$ Second, because the meaning of Weber's "welfare" is not formulated either negatively or positively, ${ }^{36}$ the depth of its meaning also indicates that it is incompatible with the due care theory. The basic norm of the theory is not to harm others in their activities. ${ }^{37}$ Do notharm others (ojo mitunani wong liyo) is the most important moral norm or basic principle of Javanese social ethics, ${ }^{38}$ including its trade ethos which will be discussed in the next sub-chapter.

The second critical attitude is related to whether Weber's theory of capitalistic ethics is appropriate for Indonesian (Javanese) Islam. According to Schrieke in Indonesia Sociological Studies (1955), he said that the capitalist mentality also appeared in Minangkabau. There was a spirit revolution similar to Weber's capitalism in Europe. ${ }^{39}$ However, according to Steenbrink, what needs to be considered is the cooperation between Islam and traders in the process of expansion. It is not a coincidence of co-operation between economic and religious phenomena. It arises from the true nature of Islam. Among the major religions today, only Islam has grown up among traders. ${ }^{40}$

While Wertheim in Bureaucracy and Economie quoted by Taufik Abdullah explained that the ideology that drives the growth of the modern industry in Java is more likely. This is because the ideology is collectivism: it is always tolerant and syncretic. These two attitudes developed especially in the modern priyayi class. ${ }^{41}$ Wertheim's explanation is correct, but his theoretical reference is not through Weber's economic capitalism. Because the growth of the modern industry in Java was especially during the reign of King Mangkunegara IV (1853-1881) long before Weber's book "The Protestant Ethic and Spirit of Capitalism" was published in 1905. Raja Mangkunegara IV was a Javanese Muslim in the priyayi class of the palace. In that year Mangkunegaran made

\footnotetext{
${ }^{35}$ In Syed Nawab Haider Naqwi, Etika dan Ilmu Ekonomi: Suatu Sintesa Islami, trans. Husin Anis dan Asep Hidayat, (Bandung: Mizan, 1985), p. 113.

${ }^{36}$ Well-defined negatively is that humans do not feel unfairly treated and are free to gain their welfare. Positively means feeling safe, at ease, safe according to ideals with its values. Franz Magnis Suseno, Kuasa dan...., op. cit., p. 44.

${ }^{37}$ K.Bertens, Pengantar Etika Bisnis, (Jakarta: Gramedia, 2000), Pp. 236-237.

${ }^{38}$ Franz Magnis Suseno, Kuasa dan Moral, (Jakarta: PT SUN, 2001), p. 168.

${ }^{39}$ BJO Schrieke, Indonesia Sociological Studies, (Bandung: NV Mij Vorkink-van Hoeve, 1960), p. 99.

${ }^{40}$ Karel Steenbrink, Mencari Tuhan dengan Kaca Mata Barat, (Yogyakarta: t.p., 1987), p. 31.

${ }^{41}$ Taufik Abdullah (ed.), Agama, Etos Kerja dan Perkembangan Ekonomi, (Jakarta: LP3ES, 1982), p. 110
} 
progress, ${ }^{42}$ especially in the economic industry, namely he established sugar factories in Colomadu and Tasikmadu. ${ }^{43}$

Observing the explanation of the invalidity of the economy of capitalism in the economic industry of Mangkunegara IV as a Javanese Muslim modern priyayi class, the meaning is not the same as "modern West" in the sense of Western civilization ${ }^{44}$ nor in the sense of westernization. ${ }^{45}$ But according to Van Peursen, modern here means seeing the old (the traditional) in a new way. The trick is to sharpen the inventiveness of his thought ${ }^{46}$ by combining the two existing principles. This way of blending is something new because maybe people never thought of the combination before. 47

This explanation implies that Mangkunegara IV has a theoretical construction of the modern Javanese Muslim trade ethos in a new sense which is compatible in two ways. First, the understanding of moral values is by the depth of the meaning of Islamic objectification. Second, according to both the world view and the life of Javanese culture and its time in post-colonial conditions. But he did not dissolve into the economic system of Western capitalism (Dutch colonial). This explanation indicates the intention to study the understanding of

${ }^{42}$ See Th.G.Th. Pegeaud, Pangeran Adipati Ario Mangkunagoro IV sebagai Pujangga, trans. RT Muhammad Husodo Pringgokusumo, (Surakarta: Reksopustoko Istana Mangkunegaran, 1987), p. 3.

43Pringgodigdo, Sejarah Perusahaan-Perusahaan Kerajaan Mangkunegaran, trans. R.T. Muhamamad Husodo Pringgokusumo, (Surakarta: Reksopustoko Istana Mangkunegaran, 1987), p. 47.

${ }^{44}$ Western civilization is the dominant and universal expression of mankind. Therefore, the trend of understanding Western civilization lately is also called global civilization. Essentially, countries that are members of the Group G. Seven. Culturally and racially, Australia is Western even though geographically it is not Western. United Germany owns the East but is completely under the control of the "German" state. Akbar S. Akhmed, Post-modernisme: Bahaya dan Harapan Bagi Islam, trans. M. Sirozi, (Bandung: Mizan, 1993), p. 81.

${ }^{45}$ Westernization is, an attempt to imitate the lifestyle of Western people (Western Europeans or Americans) excessively such as clothing styles with changing fashions, ways of speaking, social manners often with denigrating national languages and associations, recreation and partying with liquor, and others. Koentjaraningrat, Kebudayaan, Mentalitas dan Pembangunan, (Jakarta: Gramnedia, 2000), p. 142.

${ }^{46}$ Sharpening inventiveness of thought means being rich in mind, smart in creativity to change views but not eliminating something but for the sake of renewal that saves new ones by rethinking a situation from within so as to find new or modern views. C.A. van Peursen, Strategi Kebudayaan, trans. Dick Hartoko, (Yogyakarta: Kanisius, 1976), p. 151.

${ }^{47}$ Ibid., p. 153. 
the theoretical construction of the Javanese Muslim trade ethos in the light of his world which is appropriate for his time as follows.

\section{The Theoretical Constructions of the Javanese Muslim Trade Ethics in Their World Views Appropriate to their Time}

According to Bertens, the word "ethos" comes from Greek which has become Indonesian, which in the Concise Oxford Dictionary (1974) explains that ethos is characterized as a characteristic of the spirit of community people or a system, a distinctive atmosphere as a sign of a group, person or system. Therefore, ethos shows as characteristics, views, values as a sign of a group or a person. ${ }^{48}$ According to Magnis Suseno, there are similarities between moral attitudes and ethos. The similarity to the absoluteness of the attitude is the difference in the stress. Moral attitude, emphasizes the orientation of norms as a standard that should be followed while ethos affirms that attitude is an attitude that is already established as a habit for a group or someone in approaching and doing a job. Therefore, the term ethos is the inner spirit or inner attitude of a person (a group of people) towards certain morals or moral values. ${ }^{49}$

This explanation, if it is related to the Javanese Muslim trade ethos in the world view according to their time, implies two things for their understanding to be analyzed. First, various moral expressions with moral values are objectified to Islam which are appropriate both in terms of world views and practices in Javanese culture in terms of trade. The two understandings of various moral values serve as a reference for appropriate moral attitudes and their success in the trade sector has been proven during its post-colonial era.

This understanding of the first point indicates that there is a close relationship between the world view and Javanese life as well as the characteristics of the culture itself. According to Gunawan, the three characteristics of Javanese culture, namely, harmony, structural function, and respect for all transcendental values are as Metaphysical, Numinous or Divine. The three of them are described in Javanese religion and the mystical literature

${ }^{48} \mathrm{~K}$. Bertens, Etika.... Op. cit., p. 225.

${ }^{49}$ Franz Magnis Suseno, Berfilsafat dari...., op. cit., p. 120. 
of Islam Kejawen is called suluk, wirid, primbon, serat or others. Transcendental nature is motivated by the belief that life is always dependent on God Almighty. ${ }^{50}$

The identification of the objectification of Islam in the world view and life, especially the Javanese Muslim trade ethos, lies in the depth of its meaning in Javanese expressions. One of the expressions most related to trading life is: timun wungkuk jogo imbuh which means cucumber is prepared as a free addition for consumers. This expression implies the meaning of what economists call externalities, namely, various factors that have economic value but are not included in the calculation. ${ }^{51}$ These factors are mainly the natural environment or natural resources, for example, cleanliness or beauty, speech, behavior when serving consumers. This factor is often considered to be powerless or trivial, the symbol of which is timun wungkuk (crooked cucumber). For the world of Javanese Muslim trading life, everything is maintained (nggo jogo imbuh) as a way of being kind or caring for the environment and others (consumers). Even though it is admittedly considered a loss, this attitude adds to the profit, namely becoming a "street advertisement" as implied in the expression tuna saktak bathi sanak which means, let the loss be a little, such as feeling annoyed or tired, but it will get profit in the brotherhood or as a customer. 52

The practical technical identification of the two Javanese expressions can be done through seven ways of being kind, namely, 1) clever in adapting to the customs of the wider community, 2) simple (prasojo) in unreasonable behaviour, 3) speaking softly or which is pleasant to hear, 4) being ethical or polite to avoid suspicion, 5) being friendly in behaving for the sake of intimacy, 6) being humble (andhapasor) even if he is of a high rank and 7) having a useful conversation or if not, it's better to be quiet The seven ways of being good or ethical are Mangkunegara IV's thoughts written in his work Serat Darmalaksita. ${ }^{53}$

${ }^{50}$ Gunawan Sumodiningrat,"Budaya Jawa dan Integrasi Nasional", in: Laila Ratna Kumala (ed.)Keraton Surakarta dan Perubahan Masyarakat: Membumikan Nilai-Nilai Tradisional, (Surakarta: Team Simposium Nasional, 2003), p. 8.

${ }^{51}$ See K. Bertens, Pengantar Etika...., op. cit., p. 139.

${ }^{52}$ See Daryono, "Etos Dagang Orang Islam Jawa dan Budaya Dagang Etnis Cina dalam Tantangan Peningkatan Perekonomian Indonesia", in Jurnal Iqtisad, Fakultas Agama Islam Universitas Hahid Hasyim Semarang, Vol. 5, No. 2, Desember 2018, p. 178.

${ }^{53}$ Sri Mangkunegara IV,"Serat Darmalaksita", in: Ki Padmasusastra, Dwidja Isjwara, (Surakarta: Abert Rusche \& Co., 1889), Pp. 98-99. 
Mangkunegara IV clarified moral values, for example how to behave in the world of Javanese Muslim trade ethos. According to him, traders should have five useful traits and eight useful ethical ways or Asta Gina. The five characteristics are careful (pangati-ati), active and serious (pethel), diligent (sregep), persevering (wekel) and, steadfast (tegen). ${ }^{54}$ While Asta Gina, namely, 1) being integrated or diligent in asking the experts (taberi tatanya), 2) cultivating businesses according to both abilities and times (panggautan gelaring pambudi), 3) creative looking for solutions (rigen), 4) understanding financial management (wruh ing petungan), 5) frugal and careful shopping (gemi), 6) thorough and careful at work (nastiti), 7) restraint for efficiency and not wasteful (nyegah kayun pepinginan...tan boros marang arto) and 8), are always patient and determined to achieve their goals in a short time (nemen ing seja, watekira sarwa gelis ingkang kinapti).55

Five traits and Asta Gina for the Javanese Muslim trade ethos which objectifies how to behave well with moral values in the world of life that are appropriate (modern) in their time there are three ways, namely 1) being kind or respectful and caring about everything 2) being good or respectful and harmonious and caring for fellow human beings and, 3) conforming to the Javanese Islamic culture or religious experience (in advance). The objectification of moral values of the three ways of being good is through each stakeholder having a proper attitude (eling) naturally (prasojo) in the dialogic process of participation in transcendental awareness, which is a process of communication between all interested parties so that they are interwoven in a dialogical communication that is free from power for the realization of transcendental interests. Like when various parties involved in trade together think about solving a problem they feel together as fellow humans. ${ }^{56}$ Through this dialogical process, each party can refrain from aja mitunani wong liya (don't harm others) and if you have to act, you will live up to two phrases: ngono yo ngono, ning ojo ngono meaning, if possible you are right but don't use any method. That's

\footnotetext{
${ }^{54}$ Sri Mangkunegara IV,"Serat Darmalaksita", in: Ki Padmasusastra, Dwidja..., op.,cit., p. 96.

${ }^{55}$ Ibid., p. 93.

${ }^{56}$ Franz Magnis Suseno, Pijar-Pijar Filsafat dari Gatholoco ke Filsafat Perempuan dari Adam Muller ke Postmodernisme, (Yogyakarta: Kanisius, 2005, p. 158.
} 
because becik ketitik ala ketara (who's good will appear and whoever is ugly will be seen). ${ }^{57}$

Magnis Suseno explained that in this process, apart from eling (being aware) and prasojo as well as ngemong, the same as having an integrated attitude, sepi ing pamrih, meaning that we should be willing to not prioritize our interests without caring for each other. Our interests are acknowledged, but not exclusively pursued. Being ngemong (cuddly) in sepi ing pamrih and aja mitunani wong liya ethoses imply the awareness that we should not think of ourselves as the center of the world, as the only thing that matters. ${ }^{58}$ That is why the Javanese Muslim trade ethos as the objectification of Islam is that they can behave both with nature and with each other for the sake of a balanced life environment, as expressed in a series of sentences: timun wungkukjogo imbuh dan tuno saktak bathi sanak.

According to Bertens, aja mitunani wong liya (don't harm others) is one of the foundations for an essential good attitude in the world of commerce, namely not to become a dirty job so that he is willing to pay attention to moral signs as in the due care theory. The point of "attention" is being willing to take the necessary action. This basic norm of not harming others is compatible with both deontological and utilitarian ethical theories, rights theories and theories of justice. ${ }^{99}$ Therefore, the theoretical construction of Javanese Muslim trade ethos has a basic ethical trade that is comprehensive.

Observing this explanation, in the world of trade ethos, Javanese Muslims are required to control various passions. The Javanese abbreviate "molimo" main (playing gambling), madon (adultery), madat, minum (drugs) and maling (stealing). ${ }^{60}$ The Javanese also try not to be selfish (egotistical) which appears in three passions: nepsu menange dewe, benere dewe dan nepsu butuhe dewe. The essence of the third meaning of lust is that people who are selfish with their behavioural characteristics tend to be adigang, adigung, adiguna that means, like to show off their power, wealth and strength or supernatural powers. Such behaviour tends to easily lead to various traits that are hated by Javanese people, namely, dahwen and open, meaning that they like to interfere in other people's

${ }^{57}$ See Daryono, “Etos Dagang Orang Islam Jawa...., op. cit., p. 181.

${ }^{58}$ Franz Magnis Suseno, Kuasa dan Moral, (Jakarta: PT SUN, 2001), p. 168.

${ }^{59}$ K.Berten, Pengantar Etika...., op. cit., Pp. 236-237.

${ }^{60}$ Ibid., p. 139. 
affairs. Drengki likes to be jealous/envy, srei: jealous/envy, jail: playing intrigue and methakil, rude/ rough. ${ }^{61}$

Traders who continue to try and succeed in controlling these various passions in addition to their (modern) trade ethic in their time in post-colonial conditions also conform to the three characteristics of Javanese culture: harmonious, structural-functional, and transcendental. The trade ethic of Muslims is as practised by the king of Mangkunegara IV with moral values that have been revealed in his various literary works in advance. Therefore, the most important point of the Javanese Muslim trade ethos goal is aja mitunani wong liya, so he is required to be eling (to know himself) and ngemong (integration) which is objectified to the world of trading life in the unity of the ethos of sepi ing pamrih. According to Bertens, sepi ing pamrih is a Javanese ethos that was not known at the time of Aristotle and includes the main ethos of faith or belief, hope and love or tresno. ${ }^{62}$ The ethos of sepi ing pamrih as an integral part of rame ing gawe means that each party should fulfil obligations according to their respective places and roles either as servants, employees, kings (state officials) or as farmers, especially as traders. ${ }^{63}$

Based on these various explanations, the trade ethic of Muslims, in particular, is always oriented or accustomed to being sepi ing pamrih, rame ing gawe is always calm and humble (andhapasor) in fulfilling various obligations. Besides being selfless, he always places himself by his meaning structurally functional in the Javanese world of life. Hence profit (profit) for him is not considered a necessity for the sake of fulfilling his satisfaction. Rather, profit is a need that can support humane progress, which is fun or happy and saves all parties (human resources and natural resources) in various fields of life.

Therefore, the aim of the efficiency of the Javanese Muslim trade ethos is that, on the one hand, as an ideal, it wants to create a state of economic harmony with efficiency engineers and on the other hand creates an atmosphere of human progress by its time in post-colonial conditions. Economic harmony is the various forces that give rise to the prosperity of the whole community if each individual pursues his interests. Efficiency engineers are people who are experts

${ }^{61}$ Soetrisno, Falsafah Hidup Pancasila..., op. cit., Pp. 22-28.

${ }^{62}$ K. Berten, Etika...., op. cit., p. 222.

${ }^{63}$ Niels Mulder, Mysticism and Everyday Life in Contemporary Java, Cultural Persistence and Change, (Singapore: Singapore University Press, 1978), p. 37. 
in the field of production methods and supervision to avoid waste and determine effective procedures. ${ }^{64}$ Humane progress is progress that can make humans feel at ease, prosperous and free to realize their dreams without being enslaved, as explained earlier.

The most important identification of the objectification of the forces that give rise to social prosperity for the Javanese Muslim trade ethos is through a participatory dialogue process on transcendental awareness. Because it is not "led" by the "invisible hand" (invisible hand) in the economic capitalism in advance. Therefore Bertens explained, what Adam Smith meant by the invisible hand was the free market mechanism, David Gauthier said, the perfect market. According to Bertens, this thought lacks practical meaning because in real competition in the market is never perfect for various reasons. For example, because of natural resources, not all people occupy the same level both in their role in the market and in their moral quality. ${ }^{65}$

This explanation implies that the depth of the moral meaning of the invisible hand in the economy of capitalism is lacking an emphasis on moral attitudes to restrain various passions such as the theoretical construction of Javanese Muslim trade ethos with evidence of its success because it has two hopes as a perspective. First, it can be a basic reference for the theoretical construction of later trade ethos thinking about the Java Regional or National level. The moral values of Javanese Muslim trade ethos and the success of Mangkunegara IV are a source of hope for a second perspective, as an alternative to an ethical vision 66 that is considered to be donated for the improvement of the economy at the regional level of Central Java or National.

\section{Conclusion}

Examining various analyzes of understanding of the moral philosophy of capitalism in the light of Javanese Muslim trade ethos can be concluded, among others:

${ }^{64}$ Winardi, Kamus Ekonomi, (Bandung: Alumni, 1984),. p. $187 .$.

${ }^{65}$ K. Bertens, Pengantar Etika...., op. cit., p. 139-141.

${ }^{66} \mathrm{An}$ Ethical vision means a view or future insight the goodness of its modern moral values which is appropriate in showing a truly new solution. See Marshal Hodgson, "Islamic Hetirage in Modern Consciousness", in Mochtar Pabottinggi (ed.), Islam Between Vision, Tradition and Non-Muslim Hegemony, (Jakarta: YOI, 1986), p. 25-26. 
The economic system of capitalism, whether Adam Smith's or Max Weber's thought implies contradictory or incompatible understanding of two things. First, it contradicts the meaning of ethos in its moral attitude because its economic goal is only for the sake of increasing one's profit in the form of money. Therefore, secondly, the basic moral attitude of the economy of capitalism tends to be selfish on the one hand, it contradicts both the theory of due concern for and its reference to human progress on the other.

The theoretical construction of Javanese Muslim trade ethos offers an alternative solution to these two things. The success of this theoretical construction was demonstrated during the reign of Mangkunegara IV (18531881) in Mangkunegaran, which was described in various Javanese literary works as objectification of Islam suitable both for the world view and the life of Javanese culture and in its time in post-colonial conditions. Evidence of its suitability is like on the one hand, if you understand the expressions of timun wungkuk jogo imbuh and tuna saktak bathi sanak and on the other hand it can create human progress, among others, the establishment of the Colomadu and Tasikmadu sugar factories so that their time was known as Kala Sumbaga (prosperous period).

\section{BIBLIOGRAPHY}

Akhmed, Akbar S., Post-modernisme: Bahaya dan Harapan Bagi Islam, terj. M. Sirozi, Bandung: Mizan, 1993.

Anderson, Benedic R.O.G., Mitologi dan Toleransi Orang Jawa, terj. Revianto B.S., Yogyakarta: Bentang Budaya, 2003.

Antlov, Hans dan Sven Cederroth (ed.), Kepemimpinan Jawa Perintah Halus Pemerintahan Otoriter, Jakarta: YOI, 2001.

Bachtiar, Harsja W, "The Religion of Java Commentary", dalam: Indonesian Journal of Cultural Studies, No,1, Vol.V, Januari 1973.

Bagus, Lorens, Kamus Filsafat, Jakarta: Gramedia, 2000.

Bertens, K, Pengantar Etika Bisnis, Yogyakarta: Kanisisus, 2000. Etika, Jakarta: Gramedia, 2005. 
Boeree, C. Goerge Personality Theories: Melacak Kepribdian Anda Bersama Psikologi Dunia, terj. Inyiak Ridwan Muzir, Yogyakarta: Prismasophie, 2005.

Cowan, J. Milton (ed.), A Dictionary of Modern Written Arabic, London: Macdonald and Evans Ltd. 1974.

Daryono, Etos Dagang Orang Jawa Pengalaman Raja Mangkunegara IV, Yogyakarta: Pustaka Pelajar, 2007.

"Etos Dagang Orang Islam Jawa dan Budaya Dagang Etnis Cina dalam Tantangan Peningkatan Perekonomian Indonesia", dalam Jurnal Iqtisad, Fakultas Agama Islam Universitas Hahid Hasyim Semarang, Vol. 5, No. 2, Desember 2018.

Dholakia, Nikhilesh (ed.), Marketing as If Cultur Mattered, University of Rhode Island: University of Rhode Preess, 1987.

Echols, John M and Hasan Shadily, An Indonesian-English Dictionary, (Ithaca: Cornell University Press, 1963.

Flew, Antony (ed.), A Dictionary of Philosophy, New York: St. Martin's Press, 1987.

Gertz, Clifford,"The Impact of the Concept of Cultur on the Concenp of Man", dalam John R. Platt (ed.), New Views of the Nature of Man, Chicago: The University of Chicago Press, 1965.

Kartodirdjo, Sartono, Protest Mouvement in Rural Java, Kuala Lumpur: Oxford University, 1973.

Kechnie, Jean L Mc, (ed), Websters New Universal Unabridged Dictionary, New York: The World Publishing Company), edisi 2, 1972.

Kodiran,"Kebudayaan Jawa",dalam: Koentjaraningrat (ed.), Anthrophology in Indonesian A Bibliograpical Review, 's-Gravenhage: Martinus Nijhoff, 1995.

Koentjaraningrat, Kebudayaan, Mentalitas dan Pembangunan, Jakarta: Gramnedia, 2000.

Kebudayaan Jawa, Jakarta: Balai Pustaka, 1994.

Rintangan-Rintangan Mental dalam Pembangunan Ekonomi di Indonesia, Jakarta: Bhratara, 1969. 
Kuntowidjojo, Identitas Politik Umat Islam Bandung: Mizan, 1997.

Lombard, Dennys, Nusa Jawa Silang Budaya: Jaringan Asia, jilid 2, Jakarta: Gramedia, 1996.

Madjid, Noor Cholish,"Mencari Akar-Akar Islam bagi Pluralisme Modern: Pengalaman Indonesia" dalam Mark Woodword, Islam in Java: Normative Piety and Mistisisme in the Sultanate of Yogyakarta, Arizona: The University of Arizona Press, 1998.

Mangkunegara IV,"Serat Darmalaksita",dalam: Ki Padmasusastra, Dwidja Isjwara, Surakarta: Albert Rusche, 1889.

Margana, S, Pujangga Jawa dan Bayang-Bayang Kolonial, Yogyakarta: Pustaka Pelajar, 2004.

Masroer Ch. Jb., Sejarah Perjumpaan Agama-Agama di Jawa, Yogyakarta: ar-Ruzz Jogjakarta, 2004.

Masruri, Siswanto, Humanitarianisme Soedjatmoko Visi Kemanusiaan Kontemporer, Yogyakarta: PILAR, 2005.

Moertono, Soemarsaid, Negara dan Usaha Bina Negara di Jawa Masa Lampau, Jakarta: YOI, 1985.

Mubyarto, Ekonomi Pancasila Gagasan dan Kemungkinan, Jakarta: LP3ES, 1993.

Muchtarom, Zaini, Islam di Jawa dalam Perspektif Santri dan Abangan, Jakarta: Salemba Diniyah, 2002.

Mudhofir, Ali, Teori dan Aliran dalam Filsafat dan Teologi, Yogyakarta: UGM Press, 1996.

Mulder, Niels, Mistisisme Jawa Ideologi Indonesia, terj. Noor Cholis, Yogyakarta: Lkis, 2001.

Mysticism and Everyday Life in Contemporary Java, Cultural Persistence and Change, Singapore: Singapore University Press, 1978.

"Dinamika Mutakhir Kebudayaan di Jawa", dalam Dinamika Pesantren, Jakarta: P3M, 1988.

Oetomo, Yacob, Dunia Usaha dan Etika Bisnis Jawa, Jakarta: Kompas, 2001.

Pabottinggi, Mochtar,"Kebudayaan dan Otosentrisitas" dalam: Agus R. Sarjono (ed.), Pembebasan Budaya-Budaya Kita, Jakarta: Gramedia, 1977. 
Peale, Kennecth Blanchard dan Norman Vincent, The Power of Ethical Management, London: Cedar Ltd., 1991.

Pegeaud, Th.G,"Pangeran Adipati Arja Mangkoenagara IV als Dichters", terj. R.Tg.Muhamad Husodo Pringgokusumo, dalam: Djawa, no. 4, Agustus 1927.

Peursen, C.A. van, Strategi Kebudayaan, terj. Dick Hartoko, Yogyakarta: Kanisius, 19976.

Pringgodigdo, R.M.Mr.A.K, Sejarah Perusahaan-Perusahaan Mangkunegara, terj. R.Tg. Muhamad Husodo Pringgokusumo, Surakarta: Yayasan Mangadeg Mangkunegaran, 1987.

Schrieke, BJO, Indonesia Sociological Studies, Bandung: NV Mij Vorkink-van Hoeve, 1960.

Simuh, Mistik Islam Kejawen Raden Ngabehi Ranggawarsita, Jakarta: UI-Press, 1988.

Soetrisno, Falsafah Hidup Pancasila sebagaimana Tercermin dalam Falsafah Hidup Orang Jawa, Yogyakarta: Pandawa, 1977.

Sitorus, Fitzgeraid K,"Identitas Dekonstruksi Permanen", dalam: Muji Sutrisno dan Hendar Putranto (ed.), Hermeneutik Pascakolonial Soal Identitas, Yogyakarta: Kanisius, 2004.

Steenbrink, Karel, Mencari Tuhan dengan Kaca Mata Barat, Yogyakarta: t. p., 1987

Sumodiningrat, Gunawan,"Budaya Jawa dan Integrasi Nasional",dalam: Laela Retna Kumala (ed.), Keraton Surakarta dan Perubahan Masyarakat, Membumikan Nilai-nilai Tradisional, Surakarta: Team Simposium Nasional, 2003.

Supriyadi, Kiai \& Priyayi Di Masa Transisi, Surakarta: Yayasan Pustaka Cakra, 2001.

Suseno, Franz Magnis, Pijar-pijar Filsafat dari Gatholoco ke Filsafat Perempuan dari Adam Muller ke Postmodernisme, Yogyakarta: Kanisius, 2005.

Etika Jawa dalam Tantangan sebuah Bunga Rampai, Yogyakarta: Kanisius, 1983. 
Etika Jawa sebuah Analisa Falsafi Kebijakan Hidup Jawa, Jakarta: Gramedia, 2001. Kuasa dan Moral, Jakarta: PT SUN, 2001. , Berfilsafat dari Konteks, Jakarta: Gramedia, 1992. 12 Tokoh Etika Abad ke 20, Yogyakarta: Kanisius, 2000.

Weber, Max, The Protestant Ethic and the Spirit of Capitalism, translate by Talcott Parson, New York: Charles Scribner's Son's, 1958.

Winardi, Kamus Ekonomi, Bandung: Alumni, 1984. 